\title{
THE REVERSAL OF THE FLYNN EFFECT AND ITS REFLECTION IN THE EDUCATIONAL ARENA: DATA COMPARISON AND POSSIBLE DIRECTIONS FOR FUTURE RESEARCH AND ACTION
}

\section{INTRODUCTION}

We live in exciting times. Technology and scientific progress take leaps a bounces forward, as we produce more knowledge, disseminate it and apply it in various domains faster than ever before in our history (Deudney, 2018). But what happens to us, humans, in the process? Are we carried on the wings of this revolution and evolve in our capacities of perceiving, reasoning and decision making or is the gap between what is available to us and what we can do with it, rapidly increasing?

For many decades most scholars and educators held the first option, and quoted two types of data to support this notion: schools achievements in most developed countries were on the rise and so were intelligence scores, a phenomenon dubbed 'the Flynn effect' (Flynn, 1984): The original study noted a significant rise in IQ score of large samples compared from the 1930 s to the late 1970s. Recently, however, evidence started suggesting the tide might be turning.

Bratsberg and Rogeberg (2018) showed that in a very large sample of Norwegians, since the late 1970s we see a dramatic fall in mean IQ scores, an opposite Flynn effect, if you will. These stirred many authors and researchers, of course, and data from other Scandinavian countries as well as Germany and young cohorts from the Netherlands seemed to corroborate these results, while data collected from the USA and South Korea does not indicate such decline

Leenu Zysberg, PhD—Associate Professor, Gordon College of Education, Haifa, Israel; correspondence address: e-mail: leehu@gordon.ac.il 
(Stillman, 2019). However data from other sources assessing academic competencies do show a slowdown in the rate of improvement if not a decrease (for example PIRLS tests for literacy in the USA, see: Sparks, 2017). These results, if nothing else suggest that the trend that seemed to demark a belief in human beings' ability to develop and cope with a world that is getting more and more complicated is changing. What may account for this change? How is it reflected in the educational arena? And why is it happening?

This manuscript discusses this phenomenon and reviews the literature on its origins. It then uses data extracted from the PISA tests from 2012 to 2015 to test the implications of the phenomenon in OECD education systems.

\section{A REVERSAL OF TREND OR A LONG BREWING CRISIS?}

By any standard, and almost any major developmental theory, one of the most important assumptions about human nature is that people have the potential to standup to the challenges of a rapidly changing world, adapt and make the most of changing circumstances (Bandura, 1998; Bennett, 2017). Against this backdrop the reversal of the trend showing a constant rise in human ability indices, can be seen as a crisis. Looking at a graphic representation of this change accentuates its acuity (see figure 1).

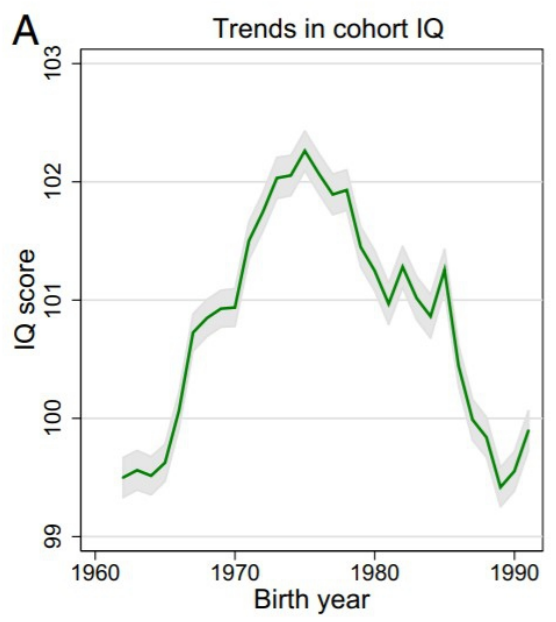

Figure 1. Changes in mean IQ grades from 1960-the early 1990s

(Presented with permission from Bratsberg and Rogeberg, 2018) 
The turning point can be seen quite clearly for people born as of the late 1970s. Such dramatic reversal may raise the question-what happened in that time or to these generations that made such a difference?

There have been, however, suggestions that technological and information advances take place at a much faster pace than changes in human competencies, thus creating a growing gap between the volume and complexity of data available and what we can and choose to do with it (e.g.: Moore's law, see: Byrne, Oliner, and Sichel, 2013). According to such models, we open a bigger and bigger gap between our technological advances and our human capabilities, thus rendering the average person less and less capable to make the best of the resources available to him. If we define 'intelligence' as the ability to solve problems in an effective and adaptive manner (Nevo, 2000), the above gap translates in practical terms to a decrease in human intelligence. Figure 2 summarizes the 'growing gap model'.

Change

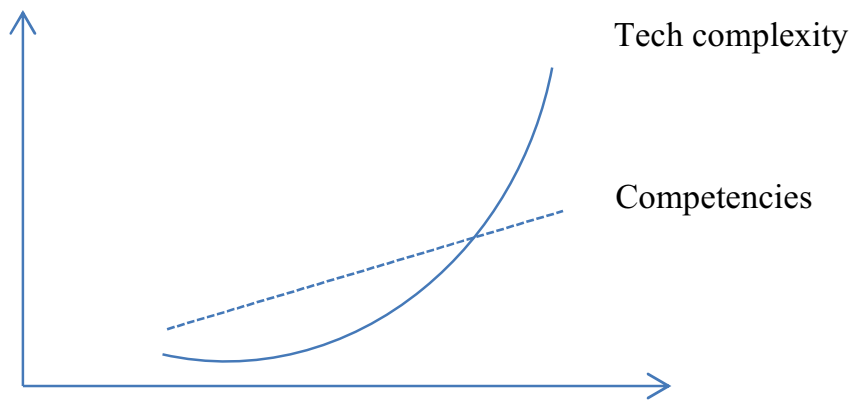

Time

Figure 2. A graphic representation of the technology-human competencies gap model

A swift reversal of trend or a gradually brewing incongruence, this change is not limited to academic studies and scientific results. Educators have been discussing the phenomenon of deteriorating academic skills among their students for a few decades now (Dieterich, 1977). Is it just a 'gut feeling' or is it the outcome of the reversed Flynn effect in education? 


\section{STUDENT ACADEMIC LITERACY LEVELS:}

\section{WHAT THE EVIDENCE SAY}

The popular media takes note of a worrying trend: students in schools and academic programs show constantly deteriorating basic academic skills and competencies: 'It is almost as if they are word blind' says a College professor, describing the quality of academic papers submitted by many of his students (Obrien, 2019). He is not alone. Various sources report dramatic decreases in basic literacy levels among college and university students in numerous countries from Ireland, to Germany, Israel and the USA, to name just a few (e.g.: Schreiber, \& Chambers, 2003; Torgesen et al., 2017). A recent OECD report suggests that $2-7 \%$ of the school graduates in the developed countries are practically illiterate (OECD, 2015).

Evidence and indices of academic performance and competencies do suggest that academic skills, mainly basic mathematical and language literacies, are dropping and are at levels that challenge education systems that struggle to push students to satisfactory level performance (e.g.: Barshay, 2017; Kershaw, 2010). This struggle is not merely academic in nature. As a result some professions struggle to get appropriately skilled workers. One of the most burning issues in this line of thought is the deteriorating quality of teachers: As students entering teacher preparation programs show deteriorating levels of competencies. Educators and policy makers wonder whether the same students will be able to meet the challenges of preparing the next generation (e.g.: Meroni, Vera-Toscano, \& Costa, 2015).

However, not too many studies and reports show systematic trends in academic skills among students and pupils, and those that do are often inconclusive. This study utilizes one of the most popular indices of academic competencies in school age-the PISA database. The PISA tests provide a standardized indication of student attainment in math, language and science. These same indicators are what is often predicted by the intelligence and cognitive ability scores discussed above (Kaufman et al., 2009). These indices may provide not only a cross country comparison of academic literacies and competencies. They may also make it possible to examine general trends-what is changing (if at all) in school students' literacy levels? 
METHOD

\section{Data extraction}

The OECD Program for International Student Assessment (PISA) conducts a series of testing batteries focusing on 15 year olds' academic literacy in the fields of Mathematics, Reading and Science. Testing takes place every 3 years. The testing batteries provide standardized grades, averaged at both local and international levels. These provide a validated indicator of academic literacies and performance at the national and cross national level (OECD, 2015).

For this study the results of PISA tests from the years 2012 and 2015 were used. To avoid excessive information (which is available to the public online) and provide an indicative picture of the data, a sample of 9 countries of the 72 included in the tests was extracted for this purpose.

\section{Sample}

An intentional sample of 9 OECD countries was taken from the general pool of included countries/ regions. Singapore, Japan and South Korea represented developed countries in the far east; The USA, the UK and Germany represented modern western countries and Poland, Russia and Greece represented more traditional developed countries (Based on indices available at worldstatistics, 2019). This sample represents approximately 67,500 tested students.

\section{Data and analysis}

For each country sampled, mean grades in Math and Reading. Science scores were not included since they were added later on in the program and may be less established as a longitudinal indicator in this stage. Scores from both time points (2012 and 2015) were extracted from the OECD PISA reports (OECD, 2012, 2015). The standardized scores range on a scale where 500 is the mean and the s.d. is 100 . Only means and difference score were calculated since at the given sample sizes, statistical significance tests are meaningless.

\section{RESULTS}

Table 1 summarizes the data depicted above and the difference is standardized score between 2012-2015 for each sample country. 
Table 1. PISA test score difference between 2012-2015

\begin{tabular}{lcccccc}
\hline Sample country & \multicolumn{3}{c}{ Math } & \multicolumn{3}{c}{ Reading } \\
& 2012 & 2015 & Difference & 2012 & 2015 & Difference \\
\hline Singapore & 573 & 564 & -9 & 542 & 535 & -7 \\
Japan & 536 & 532 & -4 & 538 & 516 & -22 \\
S. Korea & 554 & 524 & -30 & 536 & 517 & -19 \\
USA & 481 & 470 & -11 & 498 & 497 & -1 \\
UK & 494 & 492 & -2 & 499 & 496 & -3 \\
Germany & 514 & 506 & -8 & 508 & 509 & +1 \\
Poland & 518 & 504 & -14 & 518 & 506 & -12 \\
Russia & 482 & 494 & +1 & 475 & 495 & +2 \\
& & & 2 & & & 0 \\
Greece & 453 & 454 & +1 & 477 & 467 & -10 \\
\hline Mean for OECD & 494 & 493 & -1 & 493 & 490 & -3 \\
\hline
\end{tabular}

The results indicate that for the vast majority of sample countries (with the exemption of Russia, which shows a marked improvement in its indicators) either declined or stayed more or less as they were. In our sample the mean decrease is more dramatic than in the entire OECD sample and for a good reason: the sample intentionally left emerging economies, and developing countries out, to focus on relatively established systems to examine the point raised in this paper.

To put the above results in context, Figure 3 presents the mean PISA scores for the OECD in Math and Reading from 2000-2015 (all currently available data).

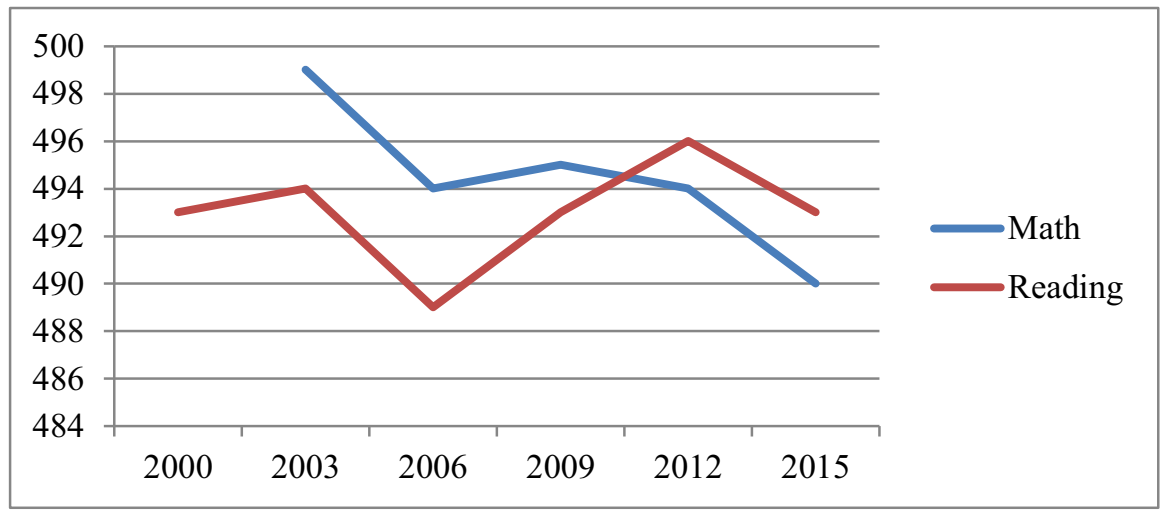

Figure 3. Mean PISA score for math and reading across the years 
The general data shows that PISA scores do not show a stable increase trend but rather a fluctuating pattern, with a tendency toward decrease (especially in math).

What can we learn from these comparisons?

\section{DISCUSSION}

Leaders, educators and researchers in the field of education have addressed the evidence from both intelligence research and its educational derivative-academic literacies - suggesting we may be approaching a crisis: can our abilities be lagging behind what's required for effectively adapting to an increasingly complex and challenging world? (Waldrop, 2016; Zysberg, 2018).

In this paper, data from the PISA tests, for an intentional sample of 9 OECD countries representing various types of developed countries, indicates that at the very least, the growth trend suggested by the Flynn effect is not taking place in the PISA results in general and especially so in the chosen sample, which did not include developing countries, the decrease (with one exception) was quite dramatic in both Math and Language literacies.

How can we account for such results and how alarming are they after all?

The most popular voices suggest that this is merely a symptom of a much broader process: Popular voices suggest that the rise of the so called 'smart technology' and its availability, cultural changes especially regarding the value of learning and knowledge, the deteriorating quality of education systems and teachers, and even nutrition and health issues that plague younger generations compared to their parents (Vyas, 2019). Most authors tend to attribute the phenomenon to environmental factors: Changes in life style (e.g.: a more sedentary life style), nutrition (e.g. consuming more industrial foods), even different games played in childhood (e.g.: action shooter computer games) were mentioned as possible factors (Dockrill, 2018).

An additional line of this discussion focuses on state level systems, such as the allocation of resources to education: General government spending on education and even more specifically, spending on education per student associates with student achievement (OECD, 2015). While economic factors have been consistently associated with academic performance in most education systems (Bakker, Denessen, \& Brus-Laeven, 2007), it is interesting to 
note that some of the larger decreases in PISA scores were observed in robust economies (e.g.: S. Korea, the USA). However this line of evidence may still suggest that social and cultural priorities regarding education may play an important role here.

Last but not least is looking at the results from a methodological point of view and what we know of the measurement of human competencies: Longitudinal measurement of human potentials and performance often show a bias called regression toward the mean (Rocconi \& Ethington, 2009). This may mean that countries that were either very high or very low on PISA grades may show decline (for high scores) and 'improvement' (for low scores) just as an artifact of repeated measurements. While this is a compelling option, we did see similar trends also in countries that are more or less around the OECD's mean score (e.g.: USA, Poland).

Do we need to prepare for the end of our civilization as we know it due to the erosion of basic human competencies? Are we indeed drowning ourselves in technology and information that we can use less and less effectively? While it may still be too early to reliably tell (Stillman, 2019), it is becoming clearer that we face a dramatic change in how human competencies and literacies express themselves and how we use them. Of existing possible explanations the ones that stress the roles of culture and effective resource investment in the competencies and literacy of future generations (Coburn \& Penuel, 2016) is the most likely in light of the nature of the data.

\section{Study Limitations and Directions for future thought}

Though the results reflect worldwide trends emerging from various empirical sources, the data chosen here emphasizes education related settings and is limited in scope and the level of analysis applied to it. The attempt to control potential intervening factors through the choice of intentional sample can only be partially effective, and the patterns should be read with care.

That being said, should future evidence corroborate our interim proposals and conclusions, policy makers and educators will have to team up to prevent a dangerous downslide. We live in a world that will require more and more of our ability to make sense of data and information and make effective decisions. So far we seem to fail miserably (e.g.: Lockie, 2017; Zysberg, 2018), showing a growing tendency to avoid complex information in decisions, fail to differentiate bogus facts, facts and opinions, and find it more and more difficult to represent our perceptions and insights in an effective 
manner. Will saving the human race from itself be the next task at hand for educators? Only the future can tell.

\section{REFERENCES}

BAKker, J., Denessen, E., \& Brus-LAeven, M. (2007). Socio-economic background, parental involvement and teacher perceptions of these in relation to pupil achievement. Educational Studies, 33(2), 177-192.

BANDuRA, A. (1998). Personal and collective efficacy in human adaptation and change. Advances in psychological science, 1, 51-71.

BARShAY, J. (2017). Third indication U.S. educational system is deteriorating. The Hechinger Report, December, 11, Retrieved from: https://hechingerreport.org/third-indication-u-s-educational -system-deteriorating/.

BENNETT, J.W. (2017). The ecological transition: cultural anthropology and human adaptation. London: Routledge.

Bratsberg, B., \& Rogeberg, O. (2018). Flynn effect and its reversal are both environmentally caused. Proceedings of the National Academy of Sciences, 115(26), 6674-6678.

Byrne, D.M.; OlineR, S.D.; Sichel, D.E. (March 2013). Is the Information Technology Revolution Over? (PDF). Finance and Economics Discussion Series Divisions of Research \& Statistics and Monetary Affairs Federal Reserve Board. Washington, D.C.: Federal Reserve Board Finance and Economics Discussion Series (FEDS).

Coburn, C.E., \& Penuel, W.R. (2016). Research-practice partnerships in education: Outcomes, dynamics, and open questions. Educational Researcher, 45(1), 48-54.

Deudney, D. (2018). Turbo Change: Accelerating Technological Disruption, Planetary Geopolitics, and Architectonic Metaphors. International Studies Review, 20(2), 223-231.

DieTERICH, D.J. (1977). The Decline in Student's Writing Skills: An ERIC/RCS Interview. College English, 38(5), 466-472.

DOCKRILL, P. (2018). IQ Scores Are Falling in "Worrying" Reversal of $20^{\text {th }}$ Century Intelligence Boom. Science Alert, Jan, $13^{\text {th }}$. Retrieved from: https://www.sciencealert.com/iq-scores-fallingin-worrying-reversal-20th-century-intelligence-boom-flynn-effect-intelligence.

FLynN, J.R. (1984). The mean IQ of Americans: Massive gains 1932 to 1978. Psychological Bulletin, 95(1), 29-51.

Kaufman, A.S., Kaufman, J.C., Liu, X., \& Johnson, C.K. (2009). How do educational attainment and gender relate to fluid intelligence, crystallized intelligence, and academic skills at ages 2290 years? Archives of Clinical Neuropsychology, 24(2), 153-163.

Kershaw, A. (2010). Big drop in Math skills for entering students. University Affairs, ept. $13^{\text {th }}$, Retrieved from: https://www.universityaffairs.ca/news/news-article/big-drop-in-math-skills-ofentering-students/.

LOCKIE, S. (2017). Post-truth politics and the social sciences. Environmental Sociology, 3(1), 1-5.

Meroni, E.C., Vera-Toscano, E., \& Costa, P. (2015). Can low skill teachers make good students? Empirical evidence from PIAAC and PISA. Journal of Policy Modeling, 37(2), 308-323.

Nevo, B. (2000). Human Intelligence (Part 1). Tel Aviv: The open University Press. 
ObRien, C. (2019). Student literacy levels: 'It is almost as if they are word blind.' The Irish Times, Feb., $25^{\text {th }}$. Retrieved from: https://www.irishtimes.com/news/education/student-literacy-levelsit-is-almost-as-if-they-are-word-blind-1.3803913.

OECD (2015). PISA 2015 results in focus. OECD press.

RocCONI, L.M., \& ETHINGTON, C.A. (2009). Assessing longitudinal change: adjustment for regression to the mean effects. Research in Higher Education, 50(4), 368-376.

Schreiber, J.B., \& ChAmBers, E.A. (2003). American high school seniors' mathematics literacy achievement. North American Journal of Psychology, 5(1), 15-30.

Stillman, J. (2019). Good News from Science: Humanity Might Not Be Getting Dumber After All. Retrieved from: https://www.inc.com/jessica-stillman/humanity-might-not-be-getting-dumberafter-all-new-study-suggests.html.

SparKS, S. (2017). Global Reading Scores Are Rising, But Not for U.S. Students. Education Week, Dec., $5^{\text {th }}$, Retrieved from: https://www.edweek.org/ew/articles/2017/12/05/global-reading-scores -are-rising-but-not.html.

Torgesen, J.K., Houston, D.D., Rissman, L.M., Decker, S.M., et al. (2017). Academic Literacy Instruction for Adolescents: A Guidance Document from the Center on Instruction. Center on Instruction.

VyAS, K. (2019). Are We Really Getting Dumber as Devices Get Smarter? Interesting Engineering, $J u l y, 20^{\text {th }}$. Retrieved from: https://interestingengineering.com/are-we-really-getting-dumber-asdevices-get-smarter.

WALDROP, M.M. (2016). The chips are down for Moore's law. Nature News, 530(7589), 144.

World statistics (2019). World Statistics, 2018. Retrieved from: https://world-statistics.org/.

ZYSBERG, L. (2018). Information overload and the rise of the post-fact era: on the way to some educational insights. Dvarim (Overload), 159-180 (Hebrew).

\section{ODWRÓCENIE EFEKTU FLYNNA I JEGO ODBICIE W EDUKACJI: PORÓWNANIE DANYCH I MOŻLIWE KIERUNKI DLA PRZYSZŁYCH BADAŃ I DZIAŁAŃ}

\section{Streszczenie}

Przez lata wskaźniki zdolności poznawczych i kompetencji akademickich sugerowały, że zdolność ludzi do skutecznego radzenia sobie $\mathrm{z}$ otoczeniem ulega poprawie (nazwanej efektem Flynna). Ostatnie dowody sugerują, że ten trend może się zmieniać. To badanie analizuje dane uzyskane z Programu Międzynarodowej Oceny Uczniów (Program for International Student Assessment ) dla celowej próby grupy 9 krajów w ciągu ostatnich 6 lat i sugeruje, że rzeczywiście istnieją dowody na znaczny spadek kompetencji uczniów i umiejętności czytania, pisania i matematyki poza możliwymi względami ekonomicznymi i czynnikami krajowymi. Omówiono znaczenie wyników dla edukacji i jego potencjalne implikacje.

Słowa kluczowe: kompetencje studentów; umiejętności akademickie; Efekt Flynna; PISA; edukacja. 
THE REVERSAL OF THE FLYNN EFFECT AND ITS REFLECTION

IN THE EDUCATIONAL ARENA: DATA COMPARISON AND POSSIBLE DIRECTIONS FOR FUTURE RESEARCH AND ACTION

\section{Summary}

For years indicators of cognitive abilities and academic competencies suggested that humans' ability to effective cope with their environment is improving (dubbed the Flynn effect). Recent evidence suggests that this trend may be turning. This study explores data obtained from the Program for International Student Assessment for an intentional sample of 9 countries over the last 6 years and suggests that indeed there is evidence of substantial decrease in students competencies and literacy in Language (writing) and Math beyond possible economical, and national factors. The relevance of the results to education and its potential implications are discussed.

Key words: student competencies; academic skills; Flynn effect; PISA; education. 